\title{
Uji Antibakteri Kombinasi Ekstrak Daun Belimbing Wuluh (Averrhoa bilimbi L) Dan Daun Kersen (Muntingia calabura L) Terhadap Staphylococcus aureus
}

\author{
Oktariani Pramiastuti*1, Desi Sri Rejeki², Inul Maghfiroh ${ }^{3}$, Girly Risma Firsty ${ }^{4}$ \\ 1,2,3,4 Prodi S1 Farmasi, STIKes Bhakti Mandala Husada Slawi \\ e-mail: *1 oktariani.pram@gmail.com s
}

Article Info

Article history:

Submission Mei 2020

Accepted Juni 2020

Publish Juli 2020

\begin{abstract}
Abstrak
Penyakit infeksi menjadi salah satu penyebab utama penyakit di Indonesia karena merupakan daerah yang beriklim tropis. Penyakit infeksi biasanya dapat disembuhkan dengan antibiotik, mengingat penggunaan antibiotik memiliki efek samping dan resistensi jangka panjang dan harga yang tidak terjangkau, maka diperlukan peranan tanaman herbal yang dapat melemahkan aktivitas bakteri tersebut. Tanaman kersen mengandung berbagai senyawa kimia yaitu senyawa flavonoid, saponin, dan tanin yang memiliki potensi antioksidan dan aktivitas antibakteri. Tanaman Belimbing wuluh mengandung senyawa flavonoid. Penelitian ini dilakukan untuk mengetahui aktivitas antibakteri kombinasi ekstrak daun kersen (Muntingia calabura L) dan daun belimbing wuluh (Averrhoa bilimbi L) terhadap bakteri Staphylococcus aureus. Ekstrak daun kersen dan daun belimbing wuluh diperoleh dengan metode maserasi menggunakan pelarut etanol $96 \%$ selama 5 hari. Metode difusi digunakan dalam pengujian aktivitas antibakteri dengan mengamati diameter zona hambat disekeliling cakram. Pengujian dilakukan dengan perbandingan kombinasi ekstrak daun kersen dan daun belimbing wuluh pada konsentrasi 30\% yaitu 1:1, 1:2, 2:1, 1:3 dan 3:1 terhadap Staphylococcus aureus. Hasil penelitian menunjukkan bahwa pada perbandingan kombinasi ekstrak daun kersen dan daun belimbing wuluh 1:1 memiliki daya hambat lemah, yaitu $\leq 5 \mathrm{~mm}$, sebesar 4,67 mm. Sedangkan perbandingan 1:2, 2:1, 1:3 dan 3:1 memilki daya hambat sedang karena memiliki daya hambat berkisar 5-10 mm, yaitu 6,33 mm, 7,16 mm, 7,67 mm, 7,83 mm. Rendemen ekstrak daun kersen yang diperoleh sebesar 11,94\% dan daun belimbing wuluh sebesar 6,28\%.
\end{abstract}

Kata kunci-Ekstrak daun kersen, esktrak daun belimbing wuluh, Staphylococcus aureus
Ucapan terima kasih: diberikan kepada STIKES Bhakti Mandala Husada Slawi yang telah membantu kelancaran penelitian ini

\begin{abstract}
Infectious diseases are one of the main causes of diseases in tropical regions like Indonesia. Infectious diseases usually can be cured by antibiotics, since the use of antibiotics has side effects and long-term resistance and prices that are not affordable, it needs a role of herbs that can weaken the activity of these bacteria. Kersen plants contains various chemical compounds namely flavonoid compounds, saponins, and tannins that have antioxidant potential and antibacterial activity. Belimbing wuluh contains flavonoid compounds. This research was conducted to find out the antibacterial activity of extract combination of kersen leaf (Muntingia calabura L) and belimbing wuluh leaf (Averrhoa bilimbi L) against Staphylococcus aureus. Extract of Kersen leaf and Belimbing wuluh leaf were obtained by maceration method using ethanol $96 \%$ for 5 days. The antibacterial activity test was performed by diffusion method using disc paper based on the inhibit
\end{abstract}


zone diameter or clear zone formed around the disc paper. The test was conducted by extract comparison of kersen leaf and belimbing wuluh leaf at $30 \%$ concentration namely 1:1, 1:2, 2:1, 1:3 and 3:1 against Staphylococcus aureus. The results showed that the extract comparison of kersen leaf and belimbing wuluh leaf 1:1 had a weak inhibitory power because of its inhibitory value $\leq 5 \mathrm{~mm}$, that was $4.67 \mathrm{~mm}$. While the ratio of $1: 2,2: 1,1: 3$ and 3:1 had a moderate inhibition resistance value ranges from $5-10 \mathrm{~mm} ; 6.33 \mathrm{~mm}, 7.16 \mathrm{~mm}, 7.67 \mathrm{~mm}$, and $7.83 \mathrm{~mm}$. Extract rendemen of kersen leaf was $11.94 \%$ and belimbing wuluh leaf was $6.28 \%$.

Keyword - Kersen leaf extract, belimbing wuluh leaf extract Staphylococcus aureus

DOI 10.30591/pjif.v\%vi\%i.2026

C2020Politeknik Harapan Bersama Tegal

\begin{tabular}{lr}
\hline Alamat korespondensi: & \\
Prodi DIII Farmasi Politeknik Harapan Bersama Tegal & \\
Gedung A Lt.3. Kampus 1 & \\
Jl. Mataram No.09 Kota Tegal, Kodepos 52122 & p-ISSN: 2089-5313 \\
Telp. (0283) 352000 & e-ISSN: 2549-5062 \\
E-mail: parapemikir_poltek@yahoo.com &
\end{tabular}




\section{A. Pendahuluan}

Penyakit infeksi menjadi salah satu penyebab utama penyakit di Indonesia karena merupakan daerah yang beriklim tropis. Penyakit infeksi dapat menular dari satu orang ke orang lain atau dari hewan ke manusia dan juga dapat disebabkan oleh beberapa mikroorganisme seperti bakteri, virus, parasit, dan jamur ${ }^{[1]}$. Penyakit infeksi biasanya dapat disembuhkan dengan antibiotik, mengingat penggunaan antibiotik memiliki efek samping dan resistensi jangka panjang dan harga yang tidak terjangkau, maka diperlukan peranan tanaman herbal yang dapat melemahkan aktivitas bakteri tersebut.

Indonesia merupakan salah satu negara yang memiliki lebih dari 30.000 spesies tanaman tingkat tinggi. Sistem pengobatan tradisional masih banyak digunakan 68\% penduduk dunia untuk menyembuhkan penyakit ${ }^{[2]}$. Kersen dan belimbing wuluh merupakan salah satu tanaman Indonesia yang dapat dimanfaatkan sebagai pengobatan alami. Pada umumnya, tanaman atau pohon kersen digunakan sebagai peneduh, padahal, tanaman kersen mengandung berbagai senyawa kimia yaitu senyawa flavonoid, saponin, triterpen, steroid, dan tanin yang memiliki potensi antioksidan dan aktivitas antibakteri ${ }^{[3]}$. Belimbing wuluh memiliki kandungan senyawa flavonoid seperti luteolin dan apigenin, karena kandungan senyawa tersebut, belimbing wuluh sering digunakan sebagai obat tradisional ${ }^{[4]}$.

Pada penelitian sebelumnya, menyatakan bahwa daun kersen yang diesktraksi menggunakan pelarut etanol dan metanol dengan konsentrasi larutan ekstrak yang tinggi dapat menghambat dengan baik bakteri Escherichia coli, Pseudomonas aeruginosa, Staphylococcus aureus dan Bacillus subtilis ${ }^{[3]}$. Senada dengan penelitian yang dilakukan sebelumnya pada tahun 2006 bahwa ekstrak metanol daun kersen efektif menghambat bakteri Staphylococcus aureus pada konsentrasi 10\% [4]. Ekstrak air, kloroform dan metanol daun kersen dapat menghambat bakteri Staphylococcus aureus, Escherichia coli, Pseudomonas aeruginosa, Candida albicans dan Microsporum canis ${ }^{[5]}$. Menurut Pendit et al, daun belimbing wuluh yang diekstraksi menggunaka pelarut etanol dapat menghambat aktivitas bakteri Staphylococcus aureus sebesar 13,13 mm dan sebesar 8,63 $\mathrm{mm}$ pada bakteri Escherichia coli ${ }^{[6]}$. Hasil penelitian yang dilakukan oleh Zakaria et al pada tahun 2007 menunjukkan bahwa ekstrak daun dan buah belimbing wuluh dapat menghambat bakteri Staphylococcus aureus. Sementara itu, penelitian yang dilakukan oleh Yulianingsih et al pada tahun 2012 menyatakan bahwa ekstrak etanol daun belimbing wuluh dapat menghambat bakteri Staphylococcus aureus dan Staphylococcus epidermidis pada konsentrasi $20 \%$.

Tujuan penelitian ini adalah untuk mengetahui aktivitas antibakteri kombinasi ekstrak daun kersen dan daun belimbing wuluh terhadap bakteri Staphylococcus aureus

\section{B. Metode}

Penelitian ini menggunakan desain penelitian eksperimental laboratorium untuk mengetahui aktivitas antibakteri kombinasi ekstrak etanol daun kersen (Muntingia calabura L) dan daun belimbing wuluh (Averrhoa bilimbi L.) terhadap bakteri Staphylococcus aureus. Penelitian dilaksanakan di Laboratorium Biologi Farmasi STIKes BHAMADA Slawi.

\section{Alat dan Bahan}

Alat yang digunakan cawan petri, kertas cakram, pipet volume, oven, inkubator, autoklaf, timbangan analitik, penggaris, waterbath, alat-alat gelas, jarum ose, batang L, lampu bunsen, pinset, kain flanel, kertas saring, toples kaca, batang pengaduk, cawan penguap, bejana KLT, silika gel $\mathrm{GF}_{254}$, aluminium foil, kapas dan plastik wrap.

Bahan yang digunakan daun kersen dan belimbing wuluh, bakteri Staphylococcus aureus, etanol 96\%, akuades, Nutrient Agar, $\mathrm{HCl}$ pekat, serbuk $\mathrm{Mg}, \mathrm{FeCl}_{3} 1 \%, \mathrm{NaOH} 1$ $\mathrm{N}$, asam sulfat encer $\mathrm{P}$, iodium $0,1 \mathrm{~N}, \mathrm{HCl} 2$ $\mathrm{N}$, pereaksi Mayer, etil asetat, n-heksana, asam asetat , n-butanol, kloroform, dan metanol.

\section{Pengumpulan Bahan dan Determinasi}

Daun kersen dan daun belimbing wuluh diperoleh dari desa Penusupan, Pangkah, Tegal. Pemastian identitas tumbuhan dilakukan determinasi di laboatorium Biologi Farmasi Prodi S1 Farmasi STIKes Bhakti Mandala Husada Slawi. 


\section{Pembuatan Simplisia dan Ekstrak}

Sebanyak 2 kilogram daun kersen dan daun belimbing wuluh segar disortasi basah kemudian dicuci dengan air mengalir untuk menghilangkan kotorankotoran atau benda asing. Dikeringkan untuk menghilangkan kadar air. Simplisia yang sudah kering selanjutnya dibuat serbuk. Serbuk selanjutnya di maserasi dengan etanol $96 \%$ selama 5 hari, kemudian saring dengan kertas penyaring. Filtrat yang dihasilkan kemudian diuapkan dengan waterbaht sampai didapatkan ekstrak kental ${ }^{[8]}$.

\section{Standardisasi Ekstrak}

a. Organoleptik

Organoleptik dilakukan dengan cara mengamati bentuk, warna, bau dan rasa dari ekstrak ${ }^{[8]}$.

b. Susut Pengeringan

Ekstrak sebanyak $1 \mathrm{~g}$ dimasukkan kedalam cawan porselin yang sebelumnya telah dipanaskan menggunakan oven pada suhu $105{ }^{\circ} \mathrm{C}$ selama 30 menit dan telah ditara. Cawan dimasukkan kedalam oven, keringkan pada suhu $105^{\circ} \mathrm{C}$ hingga bobot tetap, dinginkan dalam eksikator ${ }^{[7]}$.

c. Kadar Air

1 gram ekstrak dimasukan pada moisture balance. Set pada suhu $105{ }^{\circ} \mathrm{C}$ kemudian ditunggu hingga bobot tetap dan muisture balance berbunyi.

\section{Skrining Fitokimia}

\section{a. Uji Alkaloid}

Sebanyak 0,5 gram ekstrak ditambah 1 $\mathrm{mL} \mathrm{HCl} 2 \mathrm{~N}$ dan $9 \mathrm{~mL}$ air, panaskan selama 2 menit. Kemudian, dinginkan dan disaring, filtratnya ditambah 3 tetes pereaksi Mayer ${ }^{[9]}$.

b. Uji Flavonoid

Dipanaskan 0,2 gram ekstrak selama 5 menit yang telah dilarutkan dengan air. Selanjutnya 0,2 gram serbuk $\mathrm{Mg}$ dan 1 $\mathrm{mL} \quad \mathrm{HCl}$ pekat dicampurkan. Terbentuknya warna kuning, jingga atau merah menunjukkan hasil positif senyawa yang mengandung flavonoid ${ }^{[9]}$.

c. Uji Tanin

Sebanyak 0,5 gram ekstrak dipanaskan dengan $10 \mathrm{~mL}$ akuades, kemudian disaring. Filtrat ditambahkan 3 tetes larutan $\mathrm{FeCl}_{3}$ 1\%. Hasil positif ditunjukkan dengan terbentuknya warna hijau kebiruan ${ }^{[9]}$.

d. Uji Saponin
Sebanyak 0,2 gram ekstrak ditambahkan $10 \mathrm{~mL}$ akuades panas, kemudian dikocok kuat-kuat selama 10 detik. Hasil positif ditunjukan dengan terbentuk buih putih yang stabil ${ }^{[9]}$.

\section{Kromatografi Lapis Tipis}

\section{a. Alkaloid}

Sampel ditotolkan pada silika gel GF254. Elusi dilakukan dengan etanol : etil asetat : n-heksana (1:2:30). Plat dikeringkan dan diamati pada cahaya tampak, $\lambda=254 \mathrm{~nm}$ dan $\lambda=366 \mathrm{~nm}^{[10]}$.

b. Flavonoid

Sampel ditotolkan pada plat silika gel $\mathrm{GF}_{254}$. Dimasukkan ke dalam chamber yang berisi eluen asam asetat: n-butanol : air (1:3:1). Bercak yang diperoleh diperiksa dibawah sinar UV pada panjang gelombang $254 \mathrm{~nm}$ dan $366 \mathrm{~nm}^{[11]}$.

\section{c. Tanin}

Identifikasi senyawa tanin dilakukan menggunakan plat silika gel $\mathrm{GF}_{254}$ yang telah diaktivasi dalam oven dengan temperatur $100{ }^{\circ} \mathrm{C}$ dalam waktu 10 menit. Kemudian dielusi dengan fase gerak air : n-butanol : asam asetat nbutanol (5: 4: 1). Bercak yang diperoleh diperiksa dibawah sinar UV pada panjang gelombang $254 \mathrm{~nm}$ dan $366 \mathrm{~nm}^{[5]}$.

d. Saponin

Identifikasi senyawa saponin dilakukan dengan menotolkan sampel pada plat silika $\mathrm{GF}_{254}$. Dimasukkan ke dalam chamber yang berisi eluen yaitu kloroform : metanol : air (13:7:2). Selanjutnya bercak diamati dibawah sinar UV pada panjang gelombang 254 $\mathrm{nm}$ dan $366 \mathrm{~nm}{ }^{[12]}$.

\section{Uji Bebas Etanol}

Sebanyak $5 \mathrm{ml}$ ekstrak ditambah $1 \mathrm{~mL}$ $\mathrm{NaOH}$ encer konsentrasi $1 \mathrm{~N}$ dan didiamkan selama 3 menit selanjutnya ditambahkan secara perlahan-lahan $2 \mathrm{~mL}$ iodium $0,1 \mathrm{~N}$. Jika tercium iodoform dan terdapat endapan berwarna kuning dalam waktu 30menit maka bahan mengandung etanol ${ }^{[13]}$.

\section{Uji Aktivitas Antibakteri}

a. Sterilisasi alat

Alat-alat yang digunakan dalam penelitian uji aktivitas antibakteri ini disterilkan terlebih dahulu sebelum digunakan. Cawan petri dan pipet volume dibungkus dengan kertas, kemudian disterilisasi pada autoklaf dengan suhu $121{ }^{\circ} \mathrm{C}$ selama 15 menit bersama dengan 
alat-alat gelas. Jarum ose dan pinset disterilkan dengan lampu bunsen ${ }^{[14]}$.

b. Pembuatan Media Nutrient Agar (NA)

Sebanyak 11,5 g Nutrient Agar ditimbang dan dilarutkan dalam $500 \mathrm{~mL}$ akuades, lalu dipanaskan sampai bahan larut sempurna. Dimasukkan dalam tabung reaksi dan disterilkan dalam autoklaf pada suhu $121{ }^{\circ} \mathrm{C}$ selama 15 menit ${ }^{[15]}$.

c. Pembiakan Bakteri Staphylococcus ureus

Pembiakan bakteri dilakukan dengan metode tuang. Diambil satu gores bakteri menggunakan jarum ose, kemudian dilarutkan dengan akuades steril dalam tabung reaksi. Diambil $0,1 \mathrm{~mL}$ suspensi, tuangkan pada media agar, lalu ratakan dengan batang L. Kemudian diinkubasi pada suhu $37^{\circ} \mathrm{C}$ selama 24 jam.

d. Pembuatan Larutan Uji

Dibuat larutan uji dengan konsentrasi $10 \%$ dan konsentrasi 20\%. Untuk membuat konsentrasi $10 \%$ dilakukan dengan menimbang ekstrak sebanyak 1 gram kemudian dilarutkan dalam etanol $96 \%$ sebanyak $10 \mathrm{~mL}$. Sedangkan untuk konsentrasi $20 \%$ dengan menimbang ekstrak 2 gram kemudian melarutkannya dalam $10 \mathrm{~mL}$ etanol 96\%. Dari larutan uji dengan konsentrasi 10\% dan 20\% dibuat kombinasi dengan perbandingan (1:1), (1:2), (2:1), (1:3) dan (3:1) dengan volume larutan $2 \mathrm{~mL}$.

e. Uji Aktivitas Antibakteri

Metode yang digunakan dalam uji aktivitas amtibakteri yaitu difusi cakram. Kertas cakram dicelupkan dalam larutan uji selama 5 menit kemudian diletakkan diatas permukaan media Nutrient Agar yang berisi bakteri. Untuk kontrol negatif, kertas cakram dicelupkan dalam etanol $70 \%$. Dilakukan inkubasi selama 24 jam pada temperatur $37^{\circ} \mathrm{C}$ pada setiap cawan petri. Diukur diameter zona bening yang terbentuk di area kertas cakram yang menandakan terdapat daya hambat atau aktivitas antibakteri pada sampel. Pengujian dilakukan 3 kali pengulangan [16].

\section{Analisis Data}

Untuk mengetahui apakah ada perbedaan bermakna, maka data diameter zona hambat dianalisis menggunakan SPSS versi 22 dengan metode one way ANOVA.

\section{Hasil dan Pembahasan \\ 1. Determinasi Tanaman}

Laboratorium Biologi Farmasi STIKes Bhakti Mandala Husada Slawi digunakan sebagai tempat untuk melakukan determinasi tanaman. Hasil dari determinasi menyatakan bahwa sampel yang akan digunakan untuk penelitian adalah benar, yaitu Averrhoa bilimbi L (tanaman belimbing wuluh) dan Muntingia calabura L (tanaman kersen).

\section{Pembuatan Ekstrak}

Proses ekstraksi menggunakan metode maserasi dengan etanol 96\% sebagai pelarut. Hasil ekstrak kental daun kersen yang diperoleh yaitu 23,87 gram dan rendemen sebesar $11,94 \%$, sedangkan ekstrak kental daun belimbing wuluh yang diperoleh yaitu 25,14 gram dan rendemen sebesar 6,28\%.

\section{Standardisasi Ekstrak}

a. Organoleptik

Pengujian organoleptik dilakukan dengan mengamati bentuk, warna, dan bau menggunakan panca indra sebagai pengenalan awal ${ }^{[7]}$. Hasil organoleptik ekstrak daun kersen (Muntingia calabu $r a \mathrm{~L})$ dan daun belimbing wuluh (Averrhoa bilimbi L) dapat dilihat pada tabel 1.

Tabel 1. Hasil Organoleptik

\begin{tabular}{llll}
\hline \multirow{2}{*}{ No. } & Organoleptik & \multicolumn{2}{c}{ Keterangan } \\
\cline { 3 - 4 } & $\begin{array}{l}\text { Ekstrak } \\
\text { Daun } \\
\text { Kersen }\end{array}$ & $\begin{array}{l}\text { Ekstrak } \\
\text { Belimbing } \\
\text { Wuluh }\end{array}$ \\
\hline 1. & Bentuk & $\begin{array}{l}\text { Kental } \\
\text { Hijau }\end{array}$ & Kental \\
2. & Warna & Tua & Hijau Tua \\
3. & Bau & Khas & Khas \\
\hline
\end{tabular}

b. Susut Pengeringan

Penetapan susut pengeringan bertujuan untuk memberikan batasan maksimal besarnya senyawa yang hilang pada proses pengeringan. Berdasarkan hasil penelitian, diperoleh nilai susut pengeringan ekstrak daun kersen sebesar $0,34 \%$ dan nilai susut pengeringan ekstrak daun belimbing wuluh sebesar $0,70 \%$. Hasil dari susut pengeringan ini sesuai dengan literatur secara umum yang menyatakan bahwa nilai susut 
pengeringan $<10 \%{ }^{[17]}$.

c. Kadar Air

Kualitas ekstrak dapat ditetapkan menggunakan uji parameter ekstrak yaotu kadar air. Berdasarkan hasil penelitian, diperoleh kadar air ekstrak daun kersen sebesar 4,91\% dan kadar air ekstrak daun belimbing wuluh sebesar 1,69\%. Hasil dari kadar air ini sesuai dengan kadar air ekstrak secara umum yang menyatakan bahwa nilai kadar air $<10 \%{ }^{[17]}$.

\section{Skrining Fitokimia}

Skrining fitokimia dilakukan untuk mengidentifikasi senyawa yang terkandung dalam ekstrak daun kersen (Muntingia calabura L) dan daun belimbing wuluh (Averrhoa bilimbi L) secara kualitatif. Hasil skrining fitokimia dapat dilihat pada tabel 2 .

Tabel 2. Hasil Skrining Fitokimia

\begin{tabular}{|c|c|c|}
\hline \multirow[b]{2}{*}{$\begin{array}{l}\text { Golongan } \\
\text { Senyawa }\end{array}$} & \multicolumn{2}{|c|}{ Hasil Fitokimia } \\
\hline & $\begin{array}{l}\text { Ekstrak } \\
\text { Daun } \\
\text { Kersen }\end{array}$ & $\begin{array}{l}\text { Ekstrak } \\
\text { Daun } \\
\text { Belimbing } \\
\text { Wuluh }\end{array}$ \\
\hline Flavonoid & + & + \\
\hline Tanin & + & + \\
\hline Saponin & + & + \\
\hline Alkaloid & - & - \\
\hline
\end{tabular}

Uji flavonoid pada ekstrak daun kersen dan belimbing wuluh menghasilkan warna jingga setelah ditambahkan serbuk $\mathrm{Mg}$ dan $\mathrm{HCl}$ pekat hal ini menandakan ekstrak daun kersen dan belimbing wuluh positif mengandung senyawa flavonoid. Pengunaan serbuk $\mathrm{Mg}$ dan $\mathrm{HCl}$ pekat untuk mereduksi senyawa flavonoid yang terdapat pada sampel sehingga terbentuk warna jingga [18].

Daun kersen dan belimbing wuluh mengandung senyawa tanin dengan menghasilkan warna hijau kehitaman setelah ditambahkan $\mathrm{FeCl}_{3}$. Reaksi antara salah satu gugus hidroksil pada senyawa tanin dengan $\mathrm{FeCl}_{3}$ menyebabkan terjadinya warna hijau kehitaman dari ekstrak pada pengujian tanin ${ }^{[19]}$.

Uji saponin pada ekstrak daun kersen dan belimbing wuluh menghasilkan busa yang stabil hal ini menandakan terdapat senyawa saponin dalam ekstrak. Glikosida yang terdapat pada ekstrak akan terhidrolisis menjadi glukosa dan senyawa lainnya menyebabkan terbentuknya busa ${ }^{[19]}$.

\section{Kromatografi Lapis Tipis}

Pemisahan senyawa kimia berdasarkan perbedaan perbandingan distribusi dari komponen fase diam dan fase gerak dinamakan metode kromatografi lapis tipis. [20].

Hasil dari uji KLT ini menunjukan bahwa pemisahan senyawa flavonoid ekstrak daun kersen dan daun belimbing wuluh menghasilkan noda yang sama dengan noda pembanding kuersetin yaitu berwarna kuning. Pada pemisahan senyawa tanin ekstrak daun kersen menghasilkan harga Rf 0,92 dengan warna noda hijau dan pada ekstrak daun belimbing wuluh menghasilkan harga Rf 0,88 dengan warna noda hijau kecoklatan. Pemisahan senyawa saponin ekstrak daun kersen dan daun belimbing wuluh menghasilkan warna noda ungu ${ }^{[12]}$. Pemisahan senyawa alkaloid ekstrak daun kersen menghasilkan 3 bercak noda dengan nilai Rf berturut-turut sebesar 0,$17 ; 0,26$; 0,30 dengan warna noda hijau. Pada pemisahan senyawa alkaloid ekstrak daun belimbing wuluh menghasilkan 3 bercak noda dengan nilai $\mathrm{Rf}$ berturut-turut sebesar 0,$18 ; 0,28 ;$ dan 0,41 dengan warna noda hijau.


Alkaloid Flavonoloid Tanin

Saponin

Gambar 1. Kromatogram KLT Ekstrak daun Kersen


Flavonoloid Tanin

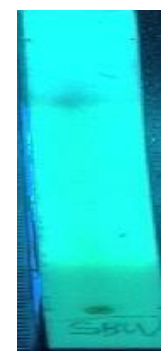

Saponin

Gambar 2. Kromatogram KLT Ekstrak daun Belimbing Wuluh 


\section{Uji Bebas Etanol}

Etanol memilik sifat sebagai antibakteri, sehingga dilakukan pengujian untuk menghilangkan kandungan etanol pada ekstrak karena dapat menggangu pada saat proses pengujian [21]. Hasil uji ini menunjukan bahwa ekstrak daun kersen (Muntingia calabura L) dan daun belimbing wuluh (Averrhoa bilimbi L) bebas dari etanol, ditandai dengan tidak terbentuk endapan kuning dan tidak timbul bau iodoform

\section{Uji Aktivitas Antibakteri}

Pengujian dilakukan menggunakan metode difusi disk yaitu dengan menggunakan kertas cakram yang diletakkan pada media agar yang telah ditanami bakteri Staphylococcus aureus. Pengukuran zona hambat dilakukan setelah media yang berisi bakteri diinkubasi selama 24 jam ${ }^{[14]}$. Sebelum dilakukan pengujian kombinasi ekstrak daun kersen dan daun belimbing wuluh, dilakukan uji pendahuluan ekstrak tunggal daun kersen $10 \%$ dan $20 \%$, ekstrak tunggal daun belimbing wuluh $10 \%$ dan $20 \%$, campuran ekstrak daun kersen $10 \%$ dan 20\%, dan campuran ekstrak daun belimbing wuluh $10 \%$ dan $20 \%$ terhadap bakteri Staphylococcus aureus. Hasil ratarata uji pendahuluan daya hambat ekstrak daun kersen dan belimbing wuluh pada bakteri Staphylococcus aureus ditunjukkan pada tabel 3 .

Tabel 3. Hasil daya hambat ekstrak daun kersen (Muntingia calabura $\mathrm{L}$ ) dan daun belimbing wuluh (Averrhoa bilimbi L) terhadap bakteri Staphylococcus aureus

\begin{tabular}{lccc}
\hline Ekstrak & $\begin{array}{l}\text { Konsentrasi } \\
10 \%(\mathrm{~mm})\end{array}$ & $\begin{array}{l}\text { Konsentrasi } \\
20 \%(\mathrm{~mm})\end{array}$ & $\begin{array}{l}\text { Campuran } \\
(\mathrm{mm})\end{array}$ \\
\hline $\begin{array}{l}\text { Daun } \\
\text { kersen }\end{array}$ & 4,83 & 7,3 & 6,83 \\
$\begin{array}{l}\text { Daun } \\
\text { belimbing }\end{array}$ & 4,1 & 6 & 6,5 \\
$\begin{array}{l}\text { wuluh } \\
\text { Kontrol } \\
\text { negatif }\end{array}$ & 0 & 0 & 0 \\
\hline
\end{tabular}

Berdasarkan kategori daya hambat menurut David Stout pada penelitian Setiowati \& Nugrahaningsih, (2015) dapat disimpulkan bahwa uji pendahuluan daya hambat ekstrak daun kersen dan belimbing wuluh pada konsentrasi $10 \%$ memiliki daya hambat lemah karena nilai daya hambat $\leq 5 \mathrm{~mm}$. Konsentrasi $20 \%$ dan campuran ekstrak daun kersen $10 \%$ dengan $20 \%$ dan campuran ekstrak daun belimbing wuluh $10 \%$ dengan $20 \%$ memiliki daya hambat sedang karena nilai daya hambat 5-10 mm. Selanjutnya dilakukan pengujian dengan mengkombinasikan ekstrak daun kersen dan daun belimbing wuluh dengan berbagai perbandingan yaitu 1:1, 1:2, 2:1, 1:3, dan 3:1. Kombinasi ekstrak daun kersen (Muntingia calabura $\mathrm{L}$ ) dan daun belimbing wuluh (Averrhoa bilimbi L) memiliki aktivitas aktibakteri terhadap bakteri Staphylococcus aureus yang ditunjukkan tabel 4.

Tabel 4. Hasil uji aktivitas antibakteri kombinasi ekstrak daun kersen (Muntingia calabura L) dan daun belimbing wuluh (Averrhoa bilimbi $\mathrm{L}$ ) terhadap bakteri Staphylococcus aureus

\begin{tabular}{clccc}
$\begin{array}{l}\text { Perbandinga } \\
\text { n Kombinasi } \\
\text { ekstrak }\end{array}$ & $\begin{array}{l}\text { Replikasi } \\
1(\mathrm{~mm})\end{array}$ & $\begin{array}{c}\text { Replikasi Replikasi } \\
2(\mathrm{~mm})\end{array}$ & $\begin{array}{l}\text { Rata- } \\
\text { rata }\end{array}$ \\
\hline $1: 1$ & 4,5 & 3,5 & 6 & 4,67 \\
$1: 2$ & 5 & 5 & 9 & 6,33 \\
$2: 1$ & 6 & 6 & 9,5 & 7,16 \\
$1: 3$ & 4,5 & 9 & 9,5 & 7,67 \\
$3: 1$ & 8 & 6 & 9,5 & 7,83 \\
\hline
\end{tabular}

Dilihat dari hasil pengujian aktivitas antibakteri, kedua ekstrak daun kersen dan belimbing wuluh memiliki sinergisme sehingga pengkombinasian ekstrak daun kersen dan belimbing wuluh dapat menghambat bakteri Staphylococcus aureus [23].

Bakteri tersusun atas protein melalui ikatan hidrogen yang dapat dibentuk oleh senyawa flavonoid dengan membemtuk kompleks. Karena terbentuknya kompleks dengan protein bakteri akan terjadi ketidakstabilan aktivitas biologi pada sel bakteri menjadi hilang. Hilangnya aktivitas biologi pada bakteri akan mengganggu permeabilitas sel bakteri dan menyebabkan kematian sel bakteri ${ }^{[24]}$.

Hasil rata-rata daya hambat kombinasi ekstrak daun kersen dan daun belimbing wuluh pada perbandingan 1:1 memiliki daya hambat lemah karena nilai daya hambatnya $\leq$ $5 \mathrm{~mm}$. Sedangkan perbandingan 1:2, 2:1, 1:3 dan 3:1 memilki daya hambat sedang karena nilai daya hambatnya 5-10 $\mathrm{mm}$. Berdasarkan nilai daya hambat tersebut 
dapat diketahui bahwa semakin besar perbandingan kombinasi ekstrak daun kersen dan daun belimbing wuluh mempunyai daya hambat yang semakin besar.

Berdasarkan uji ANOVA dapat disimpulkan bahwa tidak ada perbedaan bermakna dari setiap kelompok ekstrak daun kersen (Muntingia calabura L) dan daun belimbing wuluh (Averrhoa bilimbi L) yang dikombinasikan terhadap bakteri Staphylococcus aureus. Karena nilai signifikansinya $>0,05$ yaitu 0,384 .

\section{Simpulan}

1. Ekstrak daun kersen (Muntingia calabura L) dan daun belimbing wuluh (Averrhoa bilimbi L) yang dikombinasikan dapat menghambat bakteri Staphylococcus aureus dengan nilai daya hambat berturut-turut $4,67 \mathrm{~mm}, 6,33 \mathrm{~mm}, 7,16$ $\mathrm{mm}, 7,67 \mathrm{~mm}$, dan 7,83 mm.

2. Dari hasil ANOVA dapat disimpulkan bahwa tidak ada perbedaan bermakna dari perbandingan ekstrak daun kersen (Muntingia calabura L) dan daun belimbing wuluh (Averrhoa bilimbi L) yang dikombinasikan dalam menghambat bakteri Staphylococcus aureus.

\section{Pustaka}

[1] Brooks GF., Butel J, Morse SA. Mikrobiologi Kedokteran. Jakarta: Salemba Medika; 2005.

[2] Saifudin A, Rahayu V, Teruna HY. Standarisasi Bahan Obat Alam. Yogyakarta: Graha Ilmu; 2011.

[3] Arum Y., Supartono, Sudarmin. Isolasi dan Uji Daya Antimikroba Ekstrak Daun Kersen (Muntingia calabura). J MIPA. 2012;35(2):165-74.

[4] Zakaria ZA, Zaiton H, Henie EFP, Mat jais AM, Zainuddin ENHE. In vitro antibacterial activity of Averrhoa bilimbi L. leaves and fruits extracts. Int J Trop Med. 2007;2(3):96-100.

[5] Zakaria Z., Sufian A., Ramasamy K, Ahmat N, Sulaiman M., Arifah A., et al. In vitro antimicrobial activity of Muntingia calabura extracts and fractions. African $\mathrm{J}$ Microbiol Res. 2010;4(4):304-8.

[6] Pendit PACD, Zubaidah E, Sriherfyna FH. Karakteristik Fisik-Kimia Dan Aktivitas Antibakteri Ekstrak Daun Belimbing Wuluh (Averrhoa bilimbi
L.). J Pangan dan Agroindustri. 2016;4(1):400-9.

[7] Anonim. Parameter Standar Umum Ekstrak Tumbuhan Obat. Departemen Kesehatan Republik Indonesia. Jakarta: Departemen Kesehatan Republik Indonesia; 2000. 9-11, 16 p.

[8] Anonim. Materia Medika Indonesia Jilid 1. Jakarta: Departemen Kesehatan Republik Indonesia; 1977.

[9] Titis M, Fachriyah E, Kusrini D. Isolasi, Identifikasi dan Uji Aktifitas Senyawa Alkaloid Daun Binahong (Anredera cordifolia (Tenore) Steenis). Chem Info J [Internet]. 2013;1(1):196-201.

[10] Marliana SD, Suryanti V, Suyono. Skrining Fitokimia dan Analisis Kromatografi Lapis Tipis Komponen Kimia Buah Labu Siam ( Sechium edule Jacq . Swartz .) dalam Ekstrak Etanol. Biofarmasi. 2005;3(1):26-31.

[11] Hayati EK, Fasyah A., Sa'adah L. Fraksinasi dan identifikasi senyawa tanin pada daun belimbing wuluh (. J Kim. 2010;4(2):193-200.

[12] Fahrunnida, Pratiwi R. Kandungan Saponin Buah, Daun dan Tangkai Daun Belimbing Wuluh (Averrhoa bilimbi L .). Semin Nas Konserv dan Pemanfaat Sumber Daya Alam. 2015;1(1):220-4.

[13] Oktaviani SD, Sabikis, Hartanti D. Identifikasi Etanol Hasil Fermentasi Sente (Alocasia macrorrizha (L.)G.Don), Sente Wulung (Alocasia indica (Lour.) Koch) Dan Kimpul (Xhantosoma nigrum (Vell.) Mansf). Pharmacy. 2011;08(01):25-44.

[14] Pratiwi S. Mikrobiologi Farmasi. Jakarta: Erlangga; 2008. 188-189 p.

[15] Kusmiati, Agustini S. Uji Aktivitas Senyawa Antibakteri dari Mikroalga Prophyridium cruentum. Biodivertasi. 2007;8(1):48-53.

[16] Mulyadi M, Wuryanti, Ria P. Konsentrasi Hambat Minimum (KHM) Kadar Sampel Alang- Alang (Imperata cylindrical) Dalam Etanol Melalui Metode Difusi Cakram. J Chem Inf Model. 2013;1(1):35-42.

[17] Hana N. Formulasi Tablet Hisap Ekstrak Etanol Gambir (Uncaria gambir Roxb) Dengan Variasi Konsentrasi Polyvinyl Pyrrolidone (PVP) Sebagai Pengikat Dan Pengaruhnya Terhadap Kadar CD4 Dalam Darah. Uin. 2010;63. 
[18] Parwati N, Napitupulu M, Diah A. Uji Aktivitas Antioksidan Ekstrak Daun Binahong (Anredera Cordifolia (Tenore) Steenis) dengan 1,1-Difenil-2Pikrilhidrazil (DPPH) Menggunakan Spektrofotometer UV-Vis. J Akad Kim. 2014;3(4):206-13.

[19] Nirwana AP, Astirin OP, Widiyani T. Skrining Fitokimia Ekstrak Etanol Daun Benalu Kersen (Dendrophtoe pentandra L. Miq.). EL-VIVO. 2015;3(2):9-15.

[20] Kusumaningtyas E, Astuti E, Darmono. Sensitivitas Metode Bioautografi Kontak dan Agar Overlay Dalam Penentuan Senyawa Antikapang. J ilmu kefarmasian Indones. 2008;6(2):75-9.

[21] Eti S. Uji Aktivitas Antibakteri Ekstrak Kloroform dan Ekstrak Etanol Biji Bidara Laut (Strychnos ligustrina BI) Terhadap Staphylococcus aureus ATCC 25923 dan Salmonella thypi. J Ilm Biol Biog. 2014;2(1).

[22] Setiowati FK, Nugrahaningsih. Uji Aktivitas Antibakteri Sediaan Salep Kombinasi Gelatin Dari Kulit Kaki Ayam Dan Ekstrak Daun Binahong Terhadap Staphylococcus aureus. urnal Inf Kesehat Indones. 2015;1(2):103-6.

[23] Miksusanti, Fitrya, Marfinda N. Aktivitas Campuran Ekstrak Kulit Manggis (Garcinia mangostana L) Dan Kayu Secang (Caesalpina sappan L) Terhadap Bacillus cereus. J Penelit Sains. 2011;14(3 (C)):41-7.

[24] Saputra O, Anggraini N. Khasiat Belimbing Wuluh ( Averrhoa bilimbi L .) terhadap Penyembuhan Acne Vulgaris. Majority. 2016;5(1):76-80. 